\title{
Interaction between fish and fishing vessels in the Javanese purse seine fishery
}

\author{
Michel Potier (1), Pierre Petitgas (1) and Didier Petit ${ }^{(2)}$ \\ (1) ORSTOM, BP 5045, 34032 Montpellier Cedex 1, France. \\ (2) ORSTOM, PELFISH project, Jalan Pasir Pulih 1, Ancol Timur, Jakarta 14430, Indonesia.
}

Received August 28, 1996; accepted January 30, 1997.

Potier M., P. Petitgas, D. Petit. Aquat. Living Resour., 1997, 10, 149-156.

Abstract

The purse-seincrs of the Java Sea use light and fish aggregating devices (FAD) to concentrate and catch small pelagic fish (Decapterus sp., Amblygaster sirm, Sardinella gibhosa). This sets a question about the interaction between fish and lishing vessels. Relevant estimates of fishing mortality and fishing effort require an understanding of this interaction. To gain information on this relationship, acoustic surveys were performed on the fishing grounds and the present paper analyses these data. Using acoustic surveys, the fish density was measured and the number of schools was counted per sea surface unit. The fishing vessels were located by radar. Acoustic data were stratified into two groups, one where fishing vessels were present and the other where they were not. This stratification was tested for by resampling the data. Day and night sampled data were analysed in each strata separately. Variograms were computed to characterise spatial structure both for the fish and the purse-seiners. Contingency tables between number of schools and fish density were computed to characterise the relation between biomass and schools for the day and the night when seiners are absent or present. At night, in the absence of purse-seiners, the number of schools increase and fish rise from the bottom. In areas where purse-seiners are present this natural phenomenon is stronger. It also changes the spatial structure both of the fish density and the school abundance. The spatial structure of the vessels is similar to that of the fish density. The fishermen seem to be able to detect by day fish concentrations which will be fished later by night.

Keywords: Fishing operation, echo surveys, spatial structure, pelagic fish, Java Sea, Indonesia.

Relations poisson-navires de pêche dans la pêcherie des senneurs javanais.

Résumé

Les senneurs de la mer de Java utilisent la lumière et des radeaux pour attirer et concentrer les poissons pélagiques (Decapterus sp., Amblygaster sirm, Sardinella gibbosa). Cette technique de pêche pose la question des interactions existant entre les bateaux et le poisson. La compréhension de celles-ci peut permettre d'obtenir une estimation plus réaliste de l'effort de pêche et de la mortalité par pêche. Lors de campagnes acoustiques, la densité en poisson et le nombre de bancs ont été estimés par unité de surface. La position des senneurs a été relevée par radar. Les données acoustiques ont été stratifiées en deux groupes, l'un comprenant les senneurs et l'autre pas. Cette stratification a été validée en effectuant des réechantillonnages des données. Les données ont ensuite été analysées pour chaque groupe, de jour et de nuit. La structure spatiale du poisson et des senneurs a été caractérisée au moyen de variogrammes. Le lien entre biomasse et nombre de bancs a été étudié à l'aide de tableaux de contingence, pour le jour et Ia nuit, Iorsque les bateaux sont présents ou absents. La nuit en l'absence de senneur, le nombre de bancs augmente et du poisson localisé près du fond de jour monte vers la surface. La présence des senneurs renforce ces deux effets naturels. Dans les zones où se trouvent les senneurs, les structures spatiales du nombre de bancs et de la densité en poisson sont modifiées. La structure spatiale des senneurs est similaire à celle de la densité en poisson. Les pêcheurs semblent pouvoir détecter de jour des concentrations en poisson qu'ils pêcheront ensuite la nuit.

Mots-clés : Pêche, acoustique, structures spatiales, pélagiques, mer de Java, Indonésie. 


\section{INTRODUCTION}

As in most of the Asian pelagic purse-seine fisheries, the purse-seiners of the Java Sea use Fish Aggregative Devices (FAD) and light to concentrate the fish. Such fishing strategy uses locally the fish behaviour which makes it particularly difficult to estimate the fishing effort and the fishing mortality. Here we analyse the spatial structures both of the fishing vessels and of the fish and their interaction. The data come from acoustic surveys performed on fishing grounds during which vessel locations were recorded by radar.

The precise interaction between the fish spatial structure and the exploitation pattern has seldom been studied in the fisheries literature. Theoretical models between a fleet and a stock have been proposed at the population level without references to in situ data (Mangel and Beder, 1985; Hilborn, 1985; Allen and Mc Glade, 1986; Hilborn and Walters, 1987). Kemmerer (1980) studied in Mexico how intense nominal fishing effort affects the number and the dimension of fish schools. No spatial structure was considered. Vigneaux (1996) analyses the spatial structure of the vessel locations as no other information on the fish is available. In the present paper fish survey data and boat locations are available simultaneously. This leads us to propose an interpretative scheme for the exploitation of the small pelagics in the Java Sea by the purse-seiners. We also propose the list of parameters which determine effort and fishing mortality in that fishery.

A description of the Javanese purse-seine fishery is given in Potier and Sadhotomo (1995) and Potier and Petit (1995). On the fishing grounds, the purse-seiners search for the fish following the knowledge they have of its seasonal migrations and using a cooperative strategy. Having found the fish concentrations, each night, the purse-seiners remain anchored and concentrate the fish with light and FAD. At dawn, the purse-seiners set and during the day the boats do not fish. Depending on the catch and the fish concentration, the boats either move to another area or stand still. Therefore the boat spatial distribution is mainly stationary during the acoustic surveys on the fishing grounds (a few days).

\section{MATERIALS AND METHODS}

The data used were collected during some of the acoustic surveys performed by the Java Sea Pelagic Fishery Assessment Project. This was a multidisciplanary program financed by the EU which was jointly carried out by the French Institute of Scientific Research for Development through Cooperation (Orstom) and the Research Institute for Marine Fisheries (RIMF) which also supplied the $\mathrm{R} / \mathrm{V}$ Bawal Putih I. The project aimed at assessing and managing small pelagic resources in the Java Sea. The general ecology of the Java Sea and its seasonal cycle of salinity are described in Petit et al.
(1995). In autumn, the fleet operates mainly around the Masalembo Islands then progressively drifts to the Makassar strait. In spring, it shifts to the South China Sea near the Natuna Islands. For the purpose of the present study we focused on two acoustic surveys performed on two seasonal fishing grounds of the Java Sea purse-seiners, the Masalembo area and the Natuna area (Fig. 1).

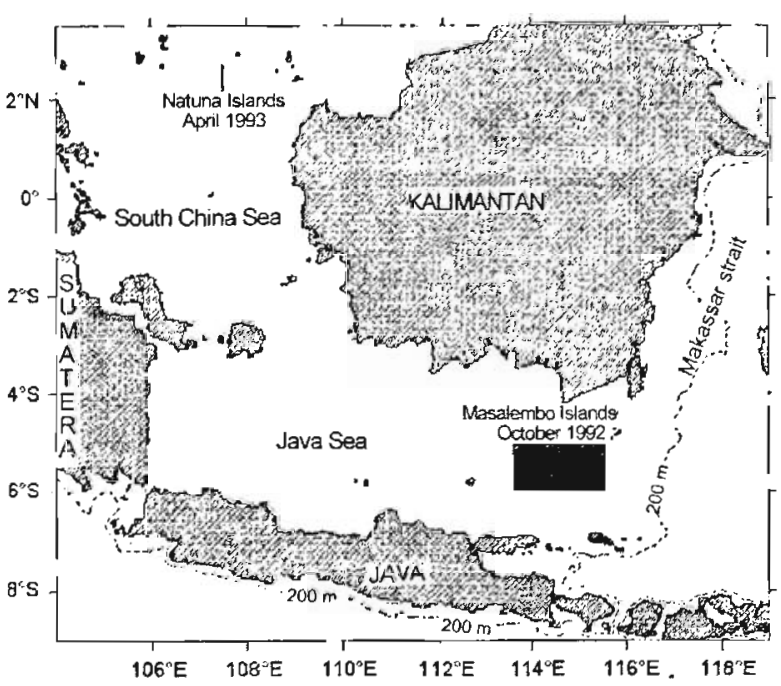

Figure 1. - Location of the two acoustic cruises used for the study.

\section{Acoustic surveys and data}

In each survey, echointegration was performed by layers and the fish density averaged every nautical mile along the ship sailing track (ESDU: Elementary Sampling Distance Unit of 1 nautical mile). Acoustic fish density was not converted into actual fish density but expressed in Unit of Integration (UI). Echointegration was performed by day and by night. Schools were identified and counted for each ESDU. The R/V Bawal Putih I surveyed at an average speed of 6 knots. Because of the proximity of the Equator and from field experience, the night and day periods were considered equal in duration, the day starting at $6 \mathrm{am}$ and the night at $6 \mathrm{pm}$. During the acoustic survey, the purse-seiners were located by radar which had a range of 15 nautical miles. In the analysis, when the distance between two boat echoes was smaller than the length of the standard seine net used in the fishery, it was considered that the same boat had been counted twice and one echo was discarded. The variables used in the study are the fish density (UI) per nautical mile ${ }^{2}$ and the number of schools per nautical mile ${ }^{2}\left(\mathrm{Nm}^{2}\right)$.

The first cruise was performed in October 1992 around the Masalembo Islands. The acoustic survey lasted 3 days and nights. The sampling design consisted of parallel equally spaced transects. The inter-transect distance was $10 \mathrm{Nm}$. This is smaller than the radar range and allowed us to count all the 
purse-seiners present in the area during the survey. 119 boats were counted along 447 ESDUs. The boats were aggregated in three major clusters. The second cruise took place in April 1993 in the South China Sea near the Natuna Islands. One cluster of fishing vessels was encountered during the cruise. It was prospected using a square design which was repeated for one day and one night. 109 boats were counted along $69 \mathrm{Nm}$.

\section{Areas of fishing vessels and data stratification}

- Areas with purse-seiners were defined using the boats in the outermost positions. Boats were clustered in space. Square limits were set to the boat clusters, parallel to the acoustic track (Fig. 2). Acoustic data were then stratified as located within the boat areas (vessel clusters) or outside. The effect of the purseseiners on the fish behaviour was tested using the ratio between night and day acoustic densities.

If the boat areas have different fish distributional characteristics, the ratio between night and day should be significantly different compared to ratios calculated for a random selection of the data. The number of acoustic observations recorded in boat areas divided by the total number of observations gives the probability, $p$, for one observation picked at random to belong to the boat areas. For each observation, we drew a random number between $0-1$. If it was lower than $p$, the observation was selected. This was performed for all the observations. Day and night average acoustic densities and their ratios were then computed on the selected observations. The procedure was repeated 200 times. This enabled us 10 generate the histogram of the density ratio for a subset of the data having

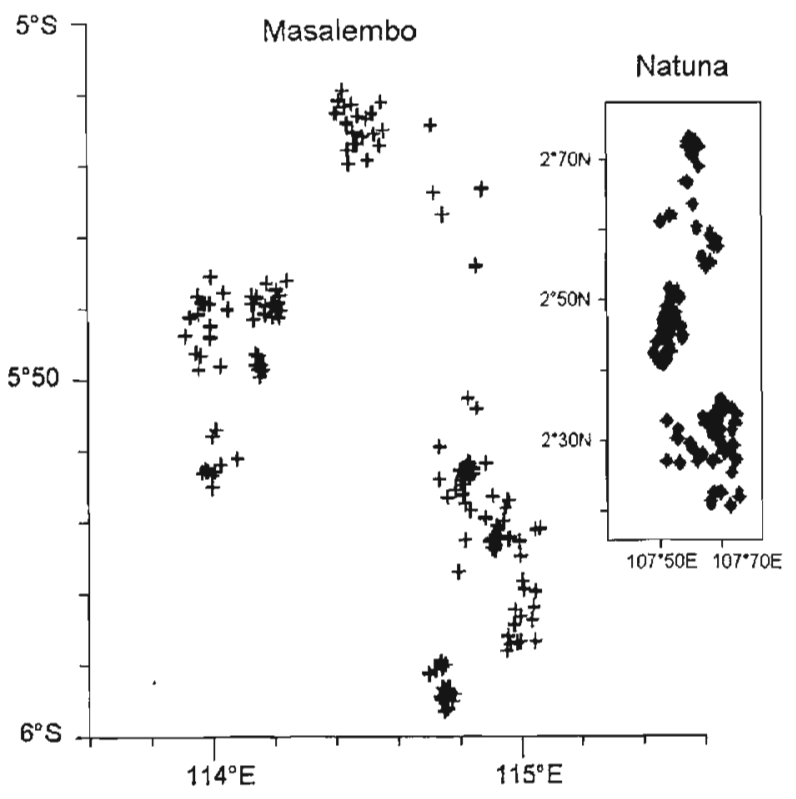

Figure 2. - Position of the purse-seiners recorded with the radar of the Bawal Putih I on the Masalembo fishing ground in October 1992 and on the Natuna fishing ground in April 1993 (+ Fishing vessels). probability $p$. The experimental ratio in the boat areas was then compared to the $p d f$ (probability distribution of frequencies) limits of the $95 \%$ quantile.

\section{Variograms}

The variogram was first introduced by Matheron (1971) to characterise spatial correlation of natural phenomena taking values at every point in space. It is now increasingly used for analysing fishery data (Pelletier and Parma, 1994; Petitgas, 1996). The variogram quantifies the discrepency between values as a function of the distance separating them. It is best interpretable when the data are homogeneous and show no trend. In general, the variogram increases with distance and reaches a sill for a given distance called the range. An increase of the variogram with distance shows spatial correlation as points farther apart are more different than closer ones. A flat variogram means no spatial correlation as close points are as different as distant ones. The range gives a quantitative measure of the average area of influence around each point. The nugget effect is a sharp increase of the variogram for the smallest distances $(g(0)=0, g(h)=c$ as soon as $h>0$ ) and quantifies a discontinuity in the spatial distribution as it measures an irreductible discrepency between very close points.

Variograms were computed using the software EVA (Petitgas and Prampart, 1995) on the acoustic density per ESDU and the number of schools per ESDU, by night and by day, inside and outside of the boat areas.

\section{Spatial distribution of fishing vessels}

In each boat area defined, all distances between two vessels were computed and the curve of the frequency of these distances was generated in order to perform analysis of the structure inside the boats areas.

\section{Bivariate distribution between schools and biomass}

We generated tables where the rows are classes of the acoustic density and the columns are classes of the school number. For each table cell, we counted the number of ESDUs as well as the biomass sum corresponding to that cell and estimated both the cell frequency in the data set and its contribution (in percent) to the total biomass. Such a table was computed for each of the four situations, inside and outside vessel clusters, during day and night time. Such tables give the shape of the bivariate distribution, density $x$ schools, in terms of biomass percentages and in terms of frequency distribution. 


\section{RESULTS}

\section{Spatial distribution of the boats}

Purse-seiners have been plotted at the same scale for Masalembo and Natuna fishing grounds (Fig. 2). Boats are clearly clustered in space. In the Natuna area, only one boat cluster was observed. Figures 3 and 4 show the superposition of the boats on the acoustic survey, both for fish density and schools per ESDU. Boat and high fish density areas do not necessarily coincide. Depending on its timing, the survey encounters the boats when they either start, end or exploit fully the fishing area.

The curves of the frequency of the distances between two boats show two modes (Fig. 5). The first one is visible between 3 and $6 \mathrm{Nm}$. Then, there is a decrease in frequency for distances of 7-10 Nm and again an increase (second mode between 12 and $16 \mathrm{Nm}$ ). The first peak corresponds to nuclei of boats concentrations in the boat areas. The distances between peripheral isolated boats and the boats in nuclei or inter-nuclei distances can explain the second mode. The boats areas are not homogeneous. The distance of $7-10 \mathrm{Nm}$ corresponds to the average diameter of boat nuclei. We computed variograms on the boat presence in small squares (not shown) which had compatible features.
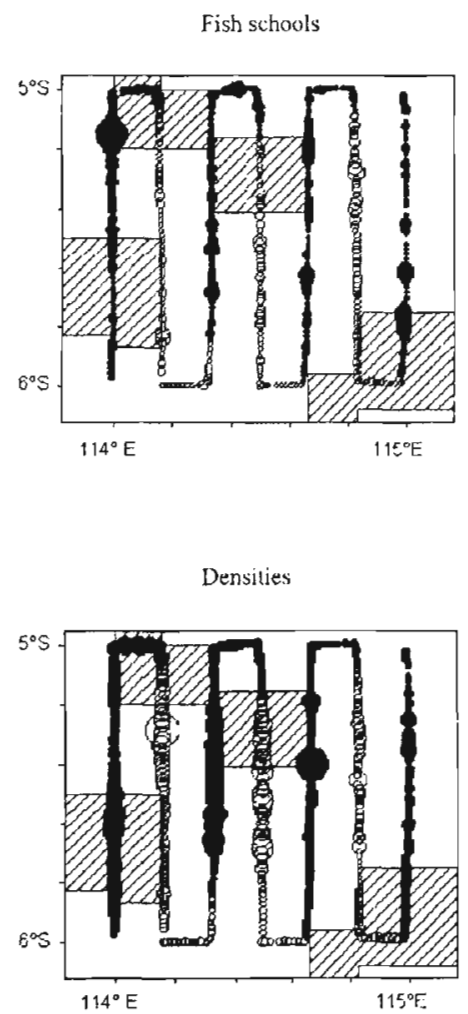

Figure 3. - Acoustic densities (UI) and number of fish schools by ESDU during the Masalembo cruise in October 1992 (hatchured area: Vessel cluster, $O$ Day, Night).
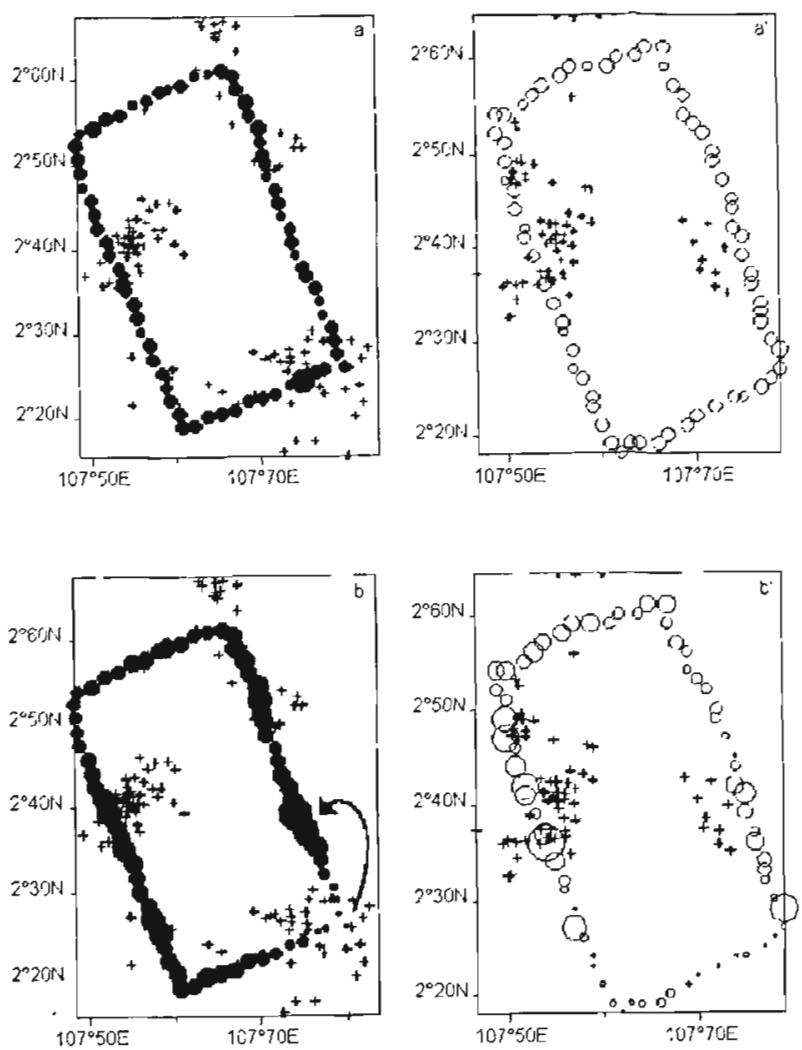

Figure 4. - Acoustic densities (UI) and number of fish schools by ESDU in the vesscl cluster surveyed during the Natuna cruise in April 1993. The arrow shows the move of some fishing vessels from the 20 th April night to the following day (+ Fishing vessels, $O$ Day, - Night).

The range was around $10 \mathrm{Nm}$ (nuclei size) and the nugget was high (heterogeneity in the nuclei).

\section{Fish inside and outside the boat areas during day and night}

Segregation of acoustic data into two groups (inside boat areas and outside these) was only performed for the Masalembo data (Fig. 3). The boat areas had a day/night ratio of the acoustic densities of 0.51 . The frequency distribution curve of the day/night ratio generated by a random selection of the data was symmetrical with mean $m=0.68$ and standard deviation $s=0.07$. The upper limit of the $2.5 \%$ left quantile was estimated by $\mathrm{m}-1.96 \mathrm{~s}=0.54$. Therefore the null hypothesis was rejected and the boat areas were considered to be significantly different $(p<0.05)$. We then characterized these differences with differences in mean values and in correlation structure. The results are summarized in Table 1 .

Outside boat areas in Masalembo, the mean acoustic density as well as the mean number of schools per ESDU increase slightly at night. But inside the boat areas, mean values are highly increased at night, by a 
Figure 5. - Curves of the distance between two boats expressed in percent of fishing vessels during the Masalembo cruise (......) and the Natuna cruise ( _ $)$.

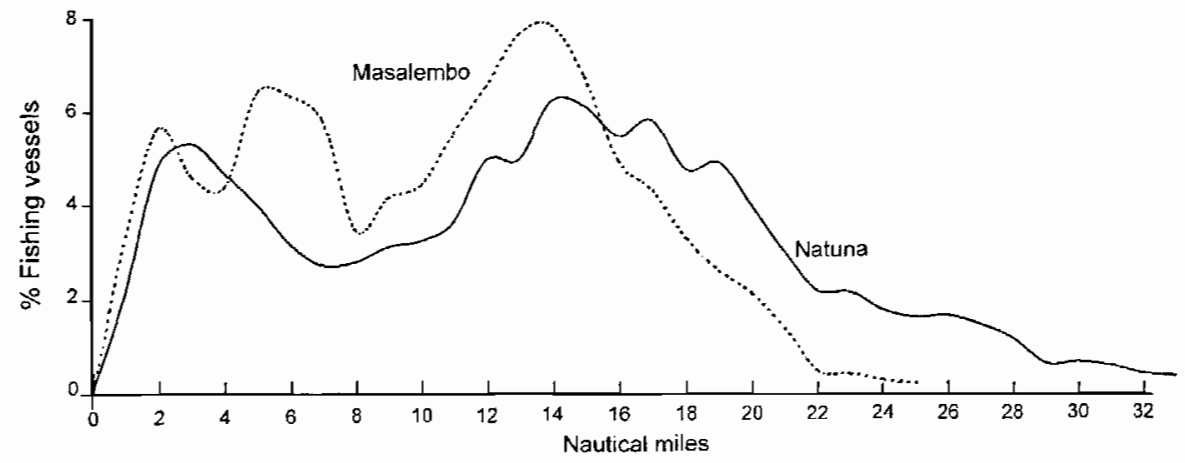

Table 1. - Acoustic data during day and night inside and outside the boat areas.

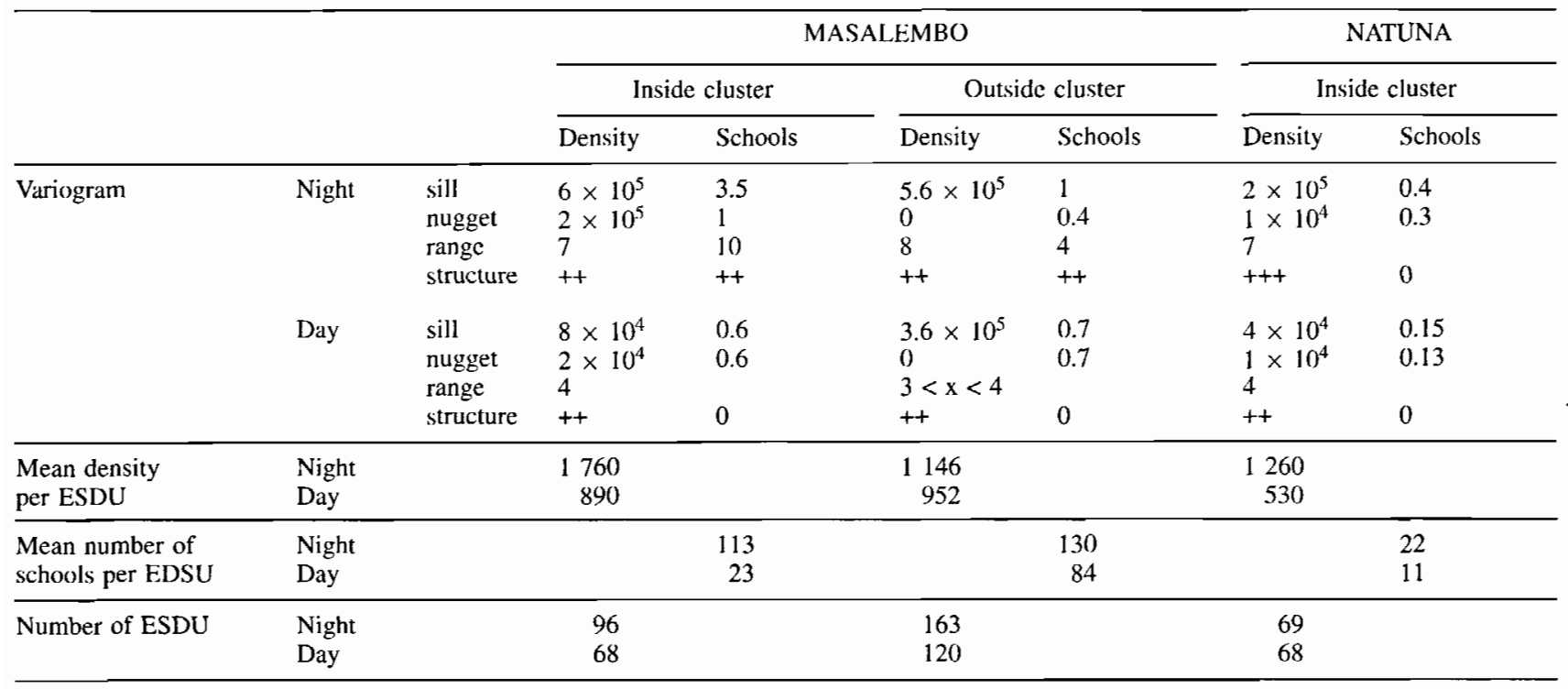

factor 3.5 in Masalembo and a factor 2 in Natuna for the number of schools and for the acoustic density, by a factor 1.5 in Masalembo and a factor 2.4 in Natuna.

Variograms for the acoustic density and the number of schools per ESDU are shown in Figure 6 . Variograms for the acoustic density show structure in and out of the vessel areas. Inside the boat areas, they show similar features in Masalembo and in Natuna. The range increases from day to night, rising from 4 to 8 nautical miles. The nugget effect increases from day to night and so does the sill. Outside the boat areas, variograms in Masalembo show an increase in the range and in the sill from day to night, but this increase is smaller than inside the boat areas. In contrast, day and night nugget effect values are similar.

The variograms for the fish schools show no structure during daytime but at night in Masalembo, structure appears inside and outside of the vessel areas. Correlation range is longer inside boat areas $(12 \mathrm{Nm})$ than outside $(4 \mathrm{Nm})$. In Natuna, schools are in too low number to see any spatial correlation at night.
The bivariate tables show similar characteristics. The probability for an ESDU to have a high biomass and many schools is higher at night than during daytime (Fig. 7). There is a higher percentage of the total biomass at night in ESDUs that contain many schools and high density (Fig. 8). This trend is much stronger in the boat areas than outside them.

\section{DISCUSSION}

We observed day/night differences in mean values and in spatial structure of the fish density and the number of fish schools. These differences occurred inside and outside boat areas but were more important in the boat areas. In these areas the acoustic density and the schools number greatly increased at night and their variograms showed a longer range, a higher nugget and a higher sill. The average dimension of the boat nuclei is comparable to the range of the night fish aggregations. Thus, there is an interaction between fish and the vessels. We propose an interpretation in 
FISH SCHOOLS

Inside the vessel clusters
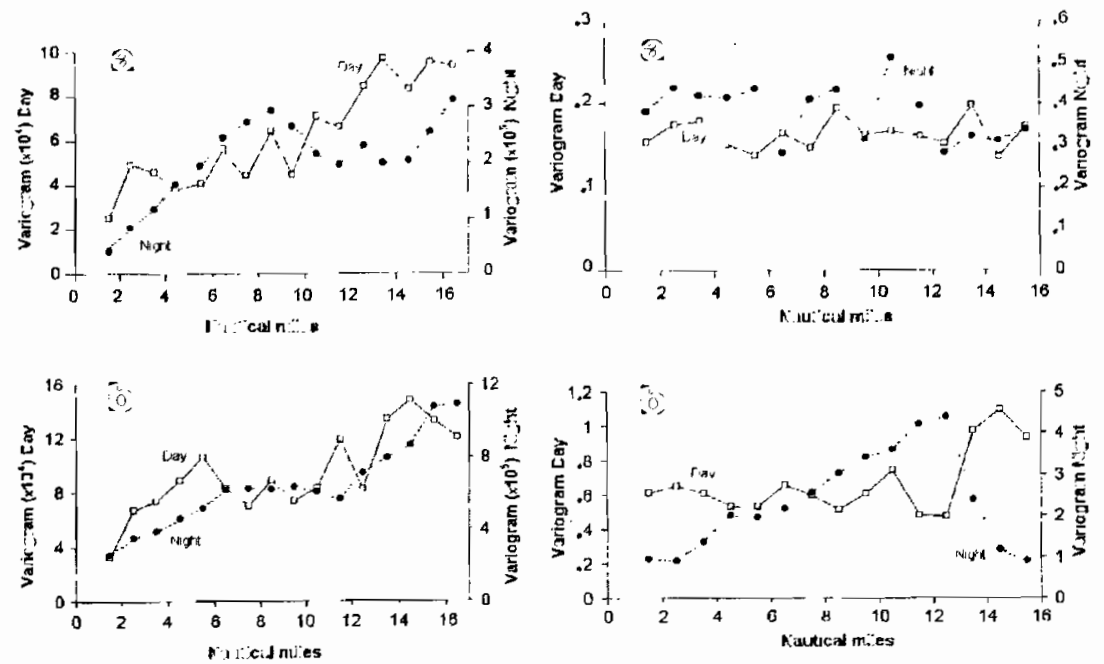

Outside the vessel clusters
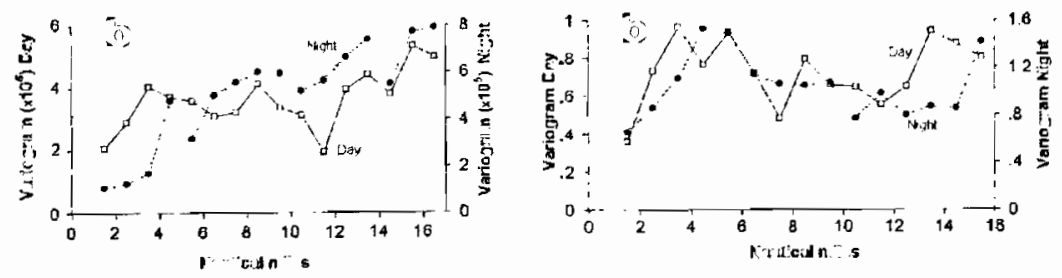

Bestianiso

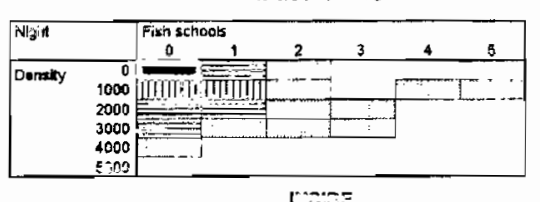

r:ะ::

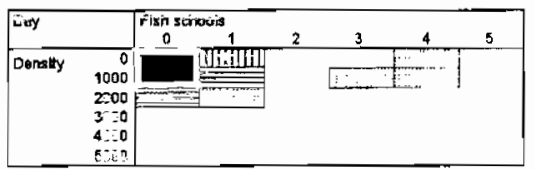

19.0.
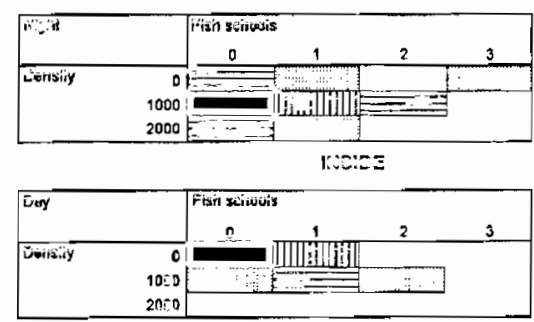

Fintre 6. - Vuriograms on the acoustic densities (left) and variograms on the fish schools (right) inside and outside the vessel clusters; a: Natuna cruise, April 1993: b: Masalembo cruise, October 1992.
Fiz:are 7. - Frequency distribution of fish schools per ESDU according to the acoustic density classes during the Masalembo cruise in October 1992 and the Natuna cruise in April 1993, inside and outside the vessel clusters. 
Figure 8. - Frequency distribution of biomass (UI; Unit of Integration) per ESDU according to the acoustic density classes during the Masalembo cruise in October 1992 and the Natuna cruise in April 1993, inside and outside the vessel clusters.
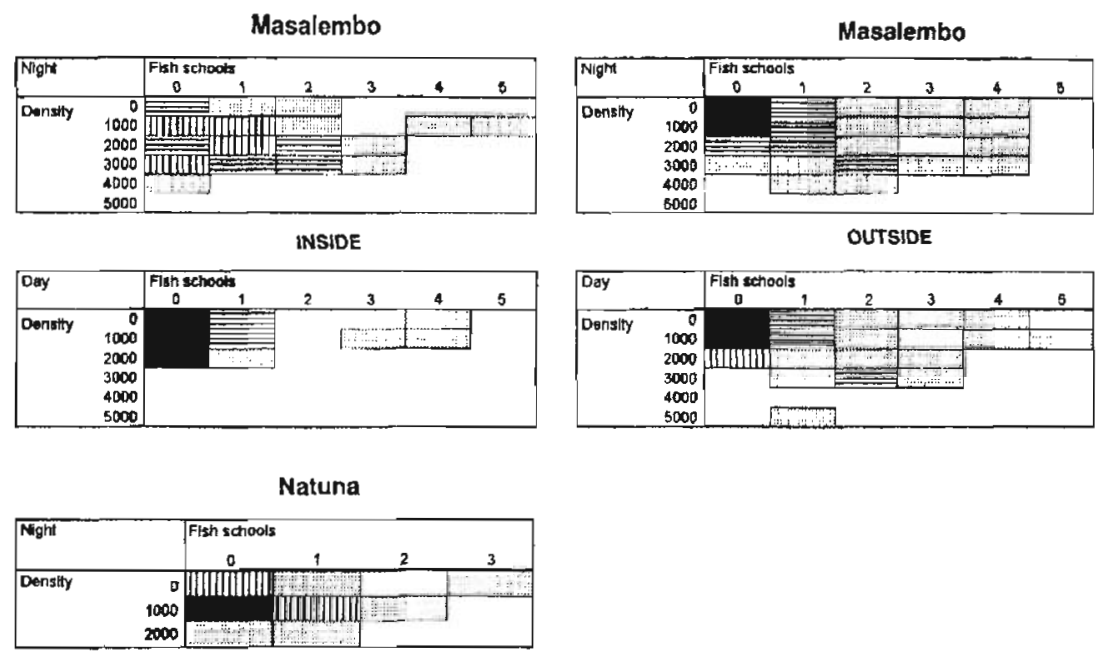

INSIDE

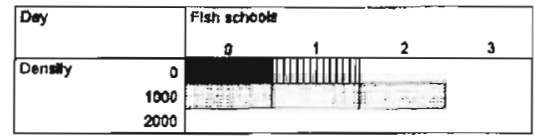

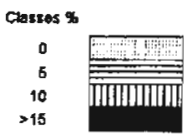

the light of the knowledge on the fishery and the fish (Potier and Sadhotomo, 1995; Potier and Petit, 1995).

It is usual for the pelagic fish to school during daytime and disperse at night. Here we observe a different behaviour which leads to think that a population of fish which was not accessible to the echosounder during daytime becomes accessible at night. The fishing vessels fish at night and stay stationary during daytime unless they change position where they will stay again stationary. Having detected the fish concentrations, the boats will occupy the space aggregated in nuclei which have a similar size than the fish concentration. These nuclei are more or less dense and form greater clusters (the boats areas). Concentration of the fish in the surroundings of each individual boat occurs each night and this concentration is then fished at dawn. With the boats staying in the sub area for several nights, the average density decreases and the heterogeneity increases. The boats modify progressively the structure starting from the small scale around each individual boat (Fig. 9). The fishermen would be able to detect where higher night fish aggregates occur and possibly increase the rise of the fish at night. In Natuna, boats probably at the end of their exploitation in a sub-area were able to locate themselves during the day in an area where at night density increased (arrow on Fig. 4).

The instantaneous area influenced by light around each boat is thought to be small. Ben Yami (1976) noted that the decrease of the illumination of a lamp in the horizontal direction is very fast. For a lamp of 12000 candela, the distance of light extinction is $15 \mathrm{~m}$. The integrated area influenced by one boat during one night is not known but according to the light power used by the Javanese purse-seiners (10$15 \mathrm{~kW}$ ) it must be greater. The echograms show

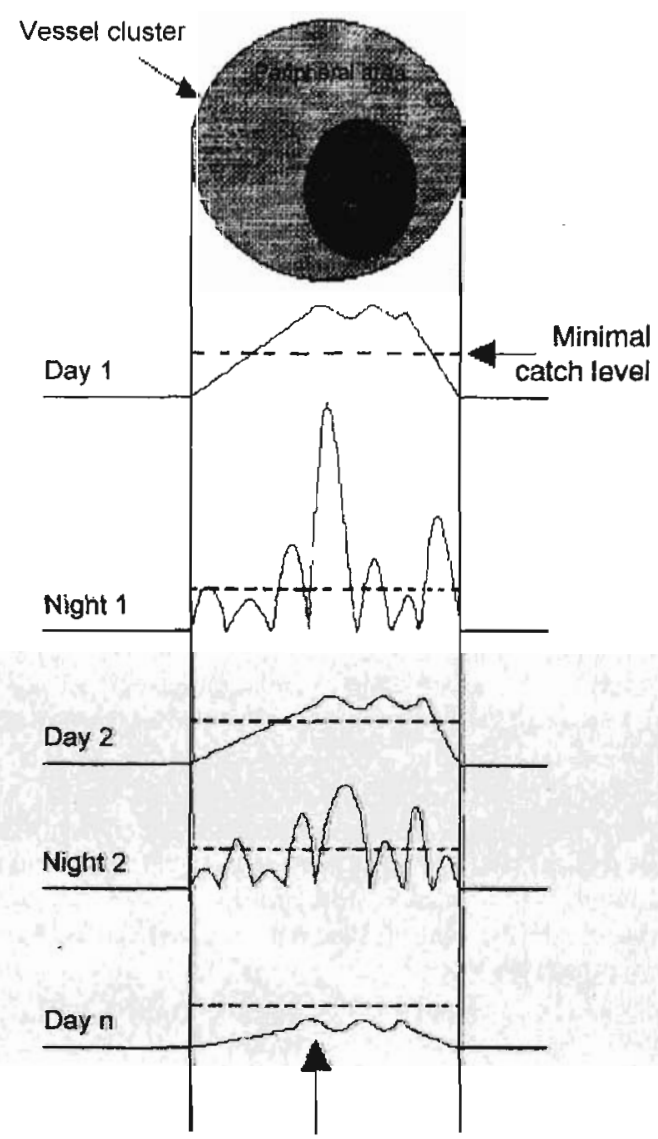

Fish density

Figure 9. - Proposed scheme of the exploitation of a fish concentration by the Javanese purse-seiners.

no sharp changes along the acoustic track performed in the vessels clusters. As the R/V "Bawal Putih" I 
never approached the fishing vessels closer than half a nautical mile, the concentration effect of the purseseiners is thought to be less than that distance. Thus we think that the fishing vessel-fish interaction studied here is at the scale of the fish concentration.

The bimodal frequency distribution of the distances between the purse-seiners is compatible with the fishing strategy used by these vessels (Potier and Petit, 1995; Hancock et al., 1996). First, there is a cooperative strategy to search the fish concentration and then competition to exploit it. We think that this strategy generates nuclei located in the core of the fish concentration, and the outer margins of the fish concentration is occupied by dispersed vessels.

For the Javanese purse-seine fishery the main parameters of the exploitation of a fishing ground are then thought to be: the number of night high fish density clusters, their average density, the threshold that determines the end of the exploitation on these clusters and the efficiency of the boats to concentrate the fish. The study of the interaction between the structure of the fishing vessels and of the fish present on a same area may allow us to better estimate the local efficiency of the boats and then to give more accurate catchability coefficients.

\section{Acknowledgments}

The present study was supported by the Pelfish Project (Java Sea pelagic Fishery Assessment project, ALA/INS/87/17) financed by EU. We wish to thank our Indonesian collcagues who were part of the Pelfish project D. Nugroho, S. Nurhakim, B. Sadhotomo, S. B. Atmaja. We are also grateful to the crew of the R/V "Bawal Putih I". We thank David Reid and two anonymous referees for valuable comments on an earlier version of the manuscript.

\section{REFERENCES}

Allen P. M., J. M. Mc Glade 1986. Dynamics of discovery and exploitation: the case of the scotian shclf groundfish fishcries. Can. J. Fish. Aquat. Sci. 43, 1187-1200.

Ben Yami 1976. Fishing with light. FAO Fish. Man., Fishing News Books Ltd., $121 \mathrm{p}$.

Hancock J., P. J. B. Hart, T. Antezena 1995. Searching behaviour and catch of horse mackerel (Trachurus murphyi) by industrial purse-seiners off south-central Chile. ICES J. Mar. Sci. 52, 991-1014.

Hilborn R. 1985. Fleet dynamics and individual variation: why some people catch more fish than others. Can. $J$. Fish. Aquat. Sci. 42, 2-13.

Hilborn R., C. J. Walters 1987. A general model for simulation of stock and flect dynamics in spatially heterogeneous fisheries. Can. J. Fish. Aquat. Sci. 44, 1366-1369.

Kemmerer A. 1980. Environmental preferences and behavior patterns of Gulf Menhaden (Brevoortia patronus) inferred from fishing and remotcly sensed data. In: Fish behavior and its use in the capture and culture of fishes. J. Bardach, J. Magnuson, R. May, J. Reinhart eds. ICLARM, Manilla, Philippines, 345-367.

Mangel M., J. H. Beder 1985. Search and stock depletion: Theory and applications. Can. J. Fish. Aquat. Sci. 42, 150-163.
Matheron G. 1971. The theory of regionalized variables and its applications. Les cahiers du CMM, 5, Ecole Nat. Sup. Mines Paris, Fontainebleau, $211 \mathrm{p}$.

Pelletier D., A. Parma 1994. Spatial distribution of Pacific Halibut (Hippoglossus stenolepis): an application of geostatistics to longline survey data. Can. J. Fish. Aquat. Sci. 51, 1506-1518.

Petit D., F. Gerlotto, N. Luong, D. Nugroho 1995. Akustikan I. ALA/INS/87/17, Sci. Tech. Doc. 21, 117 p.

Petitgas P. 1996. Geostatistics and their applications to fisheries survey data. In: Computers in Fisheries Rescarch. B. Megrey, E. Moksness eds. Chapman and Hall, 113-142.

Petitgas P., A. Prampart 1995. EVA: a gcostatistical software for structure characterisation and variance computation. Ed. Orstom, logOrstom, Paris, France, 186 p.

Potier M., D. Petit 1995. Fishing strategies and tactics in the Javanese purse-seiner fisheries. In: Biodynex. Biology, dynamics and exploitation of the small pelagic lishes in the Java Sea. M. Potier, S. Nurhakim eds. ALA/INS/87/17, Jakarta, Indonesia, 171-184.

Potier M., B. Sadhotomo 1995. Exploitation of the large and medium sciners fisheries. In: Biodynex. Biology, dynamics and exploitation of the small pelagic fishes in the Java Sea. M. Potier, S. Nurhakim eds. ALA/INS/87/17, Jakarta, Indonesia, 195-214.

Vignaux M. 1996. Analysis of spatial structure in fish distribution using commercial catch and effort data from the New Zealand hoki fishery. Can. J. Fish. Aquat. Sci. 53, 963-973. 